\title{
Subacute encephalitis with recovery in IgLON5 autoimmunity
}

Vijay K. Ramanan, MD, PhD, Brian A. Crum, MD, and Andrew McKeon, MD

Neurol Neuroimmunol Neuroinflamm 2018;5:e485. doi:10.1212/NXI.0000000000000485

Several studies have reported common presentations accompanying immunoglobulin G ( $\operatorname{IgG}$ ) antibodies targeting the neuronal cell adhesion protein IgLON5. ${ }^{1-3}$ Complex sleep and movement disorders, gait imbalance, and bulbar symptoms are prominent features. Here, we report an unusual manifestation of subacute onset encephalitis with spontaneous recovery accompanying IgLON5 autoimmunity.

\section{Case description}

A 73-year-old man with a remote renal oncocytoma history, and 2 years of difficulty with sleep initiation and maintenance, had 3 weeks of progressive gait imbalance, constipation, worsened insomnia, and confusion, followed by 5 days of headache, subjective chills, and fever. Initial testing revealed an elevated CSF protein level alone $(103 \mathrm{mg} / \mathrm{dL})$. Over 2 days, the patient continued to deteriorate, eventually requiring intubation for airway protection. On transfer to Mayo Clinic, empiric antimicrobials, antiepileptics, and dexamethasone initiated at the outside hospital were not continued. Repeat CSF studies demonstrated an elevated protein level (194 $\mathrm{mg} / \mathrm{dL}$ ) and 50 nucleated white blood cells $/ \mu \mathrm{L}$ (normal $\leq 5 / \mu \mathrm{L}$; monocyte predominant). Brain MRI revealed subtle T2 hyperintensities in the hypothalamus (figure, A and B). His neurologic status improved briskly over days with supportive care alone. He was discharged to an acute rehabilitation unit within 1 week and returned home thereafter. His serum and CSF from that hospitalization both harbored IgLON5-IgG antibodies, detected by tissue-based indirect immunofluorescence assay and confirmed by IgLON5-transfected cell-based assay. ${ }^{3}$

At 6-month follow-up, the patient reported mild residual symptoms (fatigue and insomnia without excessive daytime sleepiness, gait imbalance, and memory and word-finding difficulties). He also described occasional dysphagia, hoarseness, sialorrhea, and emotional lability, which were absent before his hospitalization. Urinary retention present during his hospitalization had resolved within weeks of onset. There were no reports of complex sleep behaviors or sleep breathing difficulties. His neurologic examiation was normal. Repeat brain MRI showed residual T2 hyperintensities in the hypothalamus (figure, C). His symptoms remained stable at 1 year. Polysomnography, neuropsychological assessment, video swallow study, whole-body fludeoxyglucose-PET (assessing for occult malignancy), and repeat brain MRI were recommended but declined by the patient.

\section{Discussion}

Neurological dysfunction punctuated by an episode of subacute encephalitis, followed by spontaneous recovery, is unusual for IgLON5 autoimmunity, which typically (but not always) has an insidious onset and course without signs of CNS inflammation. ${ }^{1}$ IgLON5 autoimmunity is known to be characterized by prominent disorders of sleep (parasomnias and sleepdisordered breathing), movement (chorea, ataxia, myoclonus, dystonia, and parkinsonism),

\author{
Correspondence \\ Dr. McKeon \\ mckeon.andrew@mayo.edu
}

From the Department of Neurology (V.K.R., B.A.C., A.M.) and Department of Laboratory Medicine and Pathology (A.M.), Mayo Clinic-Rochester, MN.

Funding information and disclosures are provided at the end of the article. Full disclosure form information provided by the authors is available with the full text of this article at Neurology.org/NN.

The Article Processing Charge was funded by the authors.

This is an open access article distributed under the terms of the Creative Commons Attribution-NonCommercial-NoDerivatives License 4.0 (CC BY-NC-ND), which permits downloading and sharing the work provided it is properly cited. The work cannot be changed in any way or used commercially without permission from the journal. 

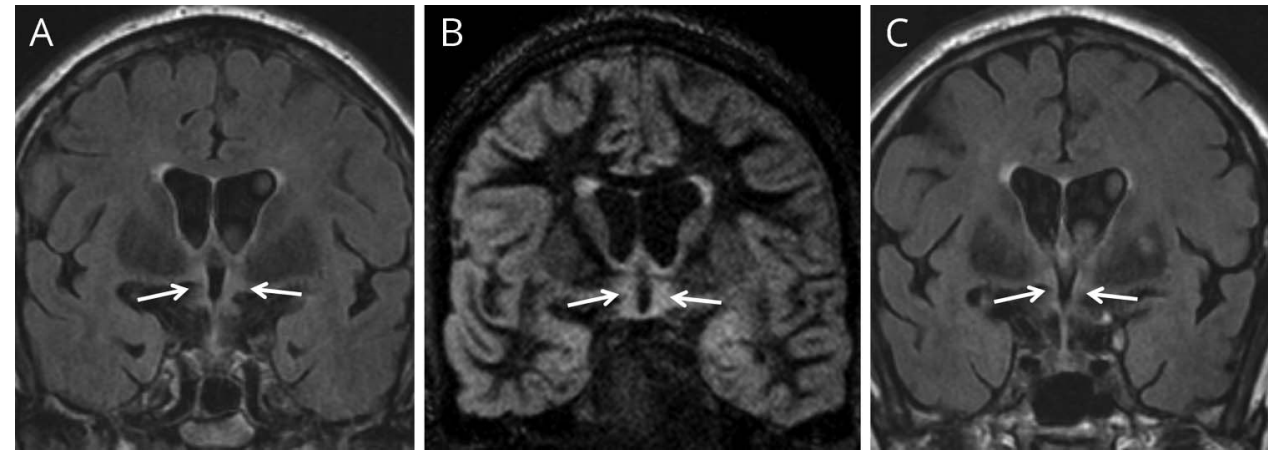

(A and B) Initial evaluation at Mayo Clinic during the subacute illness. (A) Coronal T2/FLAIR image demonstrating hyperintensities in the hypothalamus (arrows). (B) Coronal diffusion inversion recovery sequence demonstrating hyperintensities in the hypothalamus (arrows). No diffusion restriction or abnormal enhancement was identified (not shown). (C) Six-month follow-up evaluation at Mayo Clinic; coronal T2/ FLAIR image demonstrating residual hyperintensities in the hypothalamus (arrows).

brainstem dysfunction (gait instability, dysphagia, dysarthria, and oculomotor abnormalities), neuropsychiatric abnormalities, and dysautonomia. ${ }^{1,2,4}$ Other recent reports have described milder or more limited phenotypes, including isolated dysphagia ${ }^{5}$ and less pronounced sleep disorders. ${ }^{3}$

Although our patient had prominent encephalitis from which he recovered, he also had some subtle symptoms before and after the time frame of his subacute illness, supportive of the commonly described features of IgLON5 autoimmunity. In particular, he endorsed mild sleep, gait, bulbar/pseudobulbar, and cognitive complaints months after his encephalitic illness, although these did not manifest as abnormalities on neurologic examination and did not progress over 1 year of follow-up.

This patient had generic clues supportive of autoimmune encephalitis, including subacute onset of neuropsychiatric, gastrointestinal, and urinary symptoms, CSF pleocytosis, and subtle hypothalamic MRI abnormalities. Of note, the initial MRI findings of $\mathrm{T} 2$ hyperintensities in the hypothalamus in part paralleled previously reported autopsy findings of 3-repeat and 4-repeat hyperphosphorylated tau preferentially deposited in the hypothalamus, hippocampi, and brainstem tegmentum. ${ }^{6}$ Based on the radiologic findings in our patient, we speculate that tau deposition may be an end product of regional inflammation in IgLON5 autoimmunity.

Limitations of this report include the short duration of clinical follow-up and the patient's preference not to pursue ancillary testing, including polysomnography, further neuroimaging, and human leukocyte antigen typing, which may have elucidated additional features. Although the lack of formal sleep evaluation is a limitation, the mild, nonspecific features and lack of relentless progression make it unlikely that the patient's chronic insomnia was the herald symptom of IgLON5 autoimmunity. In addition, viral encephalitis cannot be ruled out as a cause of encephalitis, although multiple negative PCR test results and clinical deterioration on antiviral therapy argue against this.
We considered other reasons for encountering IgLON5 antibody in this patient. Incidental paraneoplastic antibody testing occasionally can be ascribed to the presence or history of cancer in patients without neurologic symptoms. However, IgLON5 antibody does not have known paraneoplastic significance. The argument that the IgLON5 antibody is a nonspecific "epiphenomenon" is weakened by the rarity of the finding ( 30 cases in 20 years in our laboratory), the consistent and unique neuropathology, and the fact that occasional patients meaningfully improve with immunotherapy. ${ }^{3,6,7}$

This report, among others, argues for a broadened perspective on the phenotypic scope of IgLON5 autoimmunity, particularly early in the disease course where limited or unusual presentations may occur.

\section{Author contributions}

V.K. Ramanan: report concept and design and drafting of the manuscript. B.A. Crum and A. McKeon: report concept and design and editing of the manuscript for critical intellectual content.

\section{Acknowledgment}

The authors thank the Mayo Clinic Center for Individualized Medicine and the Department of Laboratory Medicine and Pathology, Mayo Clinic, for funding and for administrative and technical support.

\section{Study funding}

This work was supported by the Mayo Clinic Center for Individualized Medicine and the Department of Laboratory Medicine and Pathology, Mayo Clinic.

\section{Disclosure}

V.K. Ramanan and B.A. Crum report no disclosures. A. McKeon has a patent pending for MAP1B as a marker of neurological autoimmunity and paraneoplastic disorders; consulted for Grifols, Medimmune, and Euroimmun without personal compensation; and received research support from Medimmune and Euroimmun. Full disclosure form information 
provided by the authors is available with the full text of this article at Neurology.org/NN.

Received April 17, 2018. Accepted in final form June 21, 2018.

\section{References}

1. Sabater L, Gaig C, Gelpi E, et al. A novel non-rapid-eye movement and rapid-eyemovement parasomnia with sleep breathing disorder associated with antibodies to IgLON5: a case series, characterisation of the antigen, and post-mortem study. Lancet Neurol 2014;13:575-586.

2. Gaig C, Graus F, Compta Y, et al. Clinical manifestations of the anti-IgLON5 disease. Neurology 2017;88:1736-1743.
3. Honorat JA, Komorowski L, Josephs KA, et al. IgLON5 antibody: neurological accompaniments and outcomes in 20 patients. Neurol Neuroimmunol Neuroinflamm 2017;4:e385. doi: 10.1212/NXI.0000000000000385.

4. Escudero D, Guasp M, Arino H, et al. Antibody-associated CNS syndromes without signs of inflammation in the elderly. Neurology 2017;89:1471-1475.

5. Schroder JB, Melzer N, Ruck T, et al. Isolated dysphagia as initial sign of anti-IgLON5 syndrome. Neurol Neuroimmunol Neuroinflamm 2017;4:e302. doi: 10.1212/NXI. 0000000000000302.

6. Gelpi E, Hoftberger R, Graus F, et al. Neuropathological criteria of anti-IgLON5related tauopathy. Acta Neuropathol 2016;132:531-543.

7. Bonello M, Jacob A, Ellul MA, et al. IgLON5 disease responsive to immunotherapy. Neurol Neuroimmunol Neuroinflamm 2017;4:e383. doi: 10.1212/NXI. 0000000000000383. 


\section{Neurology \\ Neuroimmunology \& Neuroinflammation}

Subacute encephalitis with recovery in IgLON5 autoimmunity

Vijay K. Ramanan, Brian A. Crum and Andrew McKeon

Neurol Neuroimmunol Neuroinflamm 2018;5;

DOI 10.1212/NXI.0000000000000485

This information is current as of July 20, 2018

\section{Updated Information \& Services}

References

Subspecialty Collections

Permissions \& Licensing

\section{Reprints}

including high resolution figures, can be found at:

http://nn.neurology.org/content/5/5/e485.full.html

This article cites 7 articles, 0 of which you can access for free at: http://nn.neurology.org/content/5/5/e485.full.html\#\#ref-list-1

This article, along with others on similar topics, appears in the following collection(s):

Autoimmune diseases

http://nn.neurology.org//cgi/collection/autoimmune_diseases

Insomnia

http://nn.neurology.org//cgi/collection/insomnia

Information about reproducing this article in parts (figures,tables) or in its entirety can be found online at:

http://nn.neurology.org/misc/about.xhtml\#permissions

Information about ordering reprints can be found online:

http://nn.neurology.org/misc/addir.xhtml\#reprintsus

Neurol Neuroimmunol Neuroinflamm is an official journal of the American Academy of Neurology.

Published since April 2014, it is an open-access, online-only, continuous publication journal. Copyright

Copyright (C) 2018 The Author(s). Published by Wolters Kluwer Health, Inc. on behalf of the American

Academy of Neurology.. All rights reserved. Online ISSN: 2332-7812.

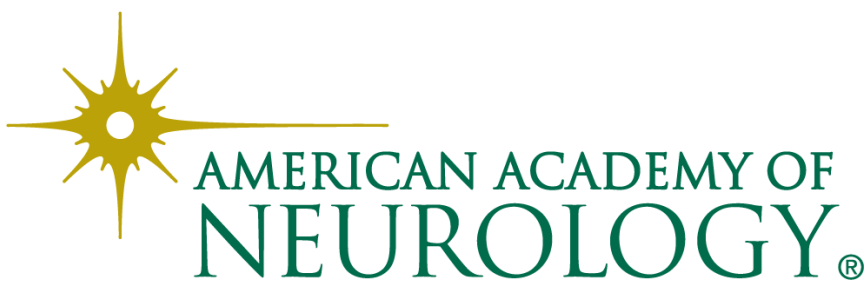

